学術論文

\title{
ローゼンブロック法によるスターラの最適設計
}

\section{Investigation of Optimal Design of LIM-type Electromagnetic Stirrer using Rosenbrock's method}

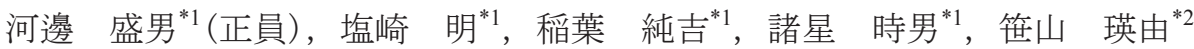

Morio KAWABE (Mem.), Akira SHIOZAKI, Junkichi INABA, Tokio MOROHOSHI, Teruyoshi SASAYAMA

The determination problem of optimum position and shape of exciting coil and teeth of LIM-type electromagnetic stirrer is discussed. 3-D magnetic field FEM analysis and Rosenbrock's method are used. Design guidelines for minimizing power capacity and maximizing flux density are examined using the objective function, that is the inverse of evaluation factor including the flux density at a specified position and load inductance. It is shown that the coil position affects mostly the performance of stirrer.

Keywords: $\quad$ stirrer, optimal design, 3-D magnetic field analysis, power capacity, load inductance.

\section{1 はじめに}

鉄鋼製品の品質向上を図るために，リニアインダク ションモータ(LIM)の原理を用いた電磁攪拌装置(以下, スターラ）が用いられている。溶鋼は，溶鉱炉 $\rightarrow$ 取鍋 ータンディッシュー鋳型の順に移動する。スターラは 溶鋼を電磁力で攪拌して介在物除去を促進させるもの で，一般には鋳型に装備されるが，近年ではタンディ ッシュでの攪拌効果が注目されている。そこで，本報 告ではタンディッシュに装備されるスターラ(片側式) を例にして，その最適構成を得るための設計手法を提 案する。

タンディッシュは溶鋼を入れる容器で熱遮蔽のた め耐火物でできておりスターラと溶鋼との磁気的なギ ヤップが大きくなるため，磁極のコイルが発生する磁 束の多くが溶湯まで至らずに漏れ磁束となる。十分に 攪拌できる電磁力を得るために指定点の磁束密度 $B_{\mathrm{P}}$ の大きさが規定されており，これを満たすためにアン ペア回数を増して磁束密度を大きくする必要があり, 大きな電源容量 $Q$ を必要とする。溶鋼の攪找速度の関 係から駆動周波数は数 $\mathrm{Hz}$ オーダになり，通常はサイ クロコンバータが用いられるが，その出力容量が消費 電力や全体の価格に関係するため，磁極とコイルの適 正化が主要な設計課題となる。スターラは大型で製作 コストも高いので，これまでの設計では特性の不具合 を避けるために，実績を基に十分余裕のある構成にな つていた。

連絡先： 河邊 盛男， $\bar{\top} 516-8550$ 三重県伊勢市竹ヶ鼻町 100, シンフォニアテクノロジー（株）開発本部研究部, e-mail: kawabe-morio@sinfo-t.jp

*1 シンフォニアテクノロジー～${ }^{* 2}$ 岡山大学
最適化手法には，Particle swarm optimization(PSO)な ど，大域的最適解を求める種々の手法を磁界解析と併 用する手法が提案されているが[1]，コストや製作性な どを試行錯誤で考慮する必要がある（付録 1）。 Rosenbrock 法(RBM)は数十回の反復で何らかの最適解 が得られるため，多くの初期值や目的関数に対する局 所解を短時間で求めることができる。

そこで本研究では，辺要素の有限要素法(FEM)によ る 3 次元磁界解析と RBM の併用法を用いて $[2,3]$, 寸 法最適化を行った。設計検討に必要な数種の目的関数 に対する解群を求め, 重回帰分析を用いて各設計変数 の効果を示し，設計者が構成検討に利用できるものに した。さらに, 磁気効率を表す評価指数 $G$ を用いるこ とにより， $B_{\mathrm{P}}$ と $Q$ の大きさやコスト，製造性とのバラ ンスを考慮した構成検討が可能になることを示した。

以下，第 2 章では 3 次元磁界解析の基本式，電源容 量の算定，目的関数の考え方を述べる。RBM の寸法 や形状を修正する繰り返しごとに要素分割を変更する 必要があるが，これを直交格子分割のスムージング法 により簡素化した[4]。RBM と 3 次元磁界解析を組み 合わせた解析では計算時間の短縮化が必要である。第 3 章では，平板形スターラのモデルを用いて 3 次元の 静磁界解析を適用してもよいことを示した。第 4 章で は設計変数を設定し, 各種の目的関数に対して最適化 計算を行った。種々の目的関数に対して得られた解を 重回帰分析し，提案した設計手法の有効性を述べた。

\section{2 計算方法}

\subsection{3 次元磁界解析}


辺要素を用いた $\boldsymbol{A}$ 一 $\boldsymbol{\phi}$ 法による 3 次元渦電流解析の 基礎方程式は次式で与えられる。

$$
\operatorname{rot}(v \operatorname{rot} A)=\boldsymbol{J}_{0}-j \omega \sigma A
$$

ここで, $\boldsymbol{A}$ : 磁気ベクトルポテンシャル, $J_{0}$ : 強制 電流密度, $v$ : 磁気抵抗率, $\sigma$ : 導電率, $\omega$ : 角周波数 である。(1)式では複素数近似法を用い，静磁界解析の 場合は $\sigma$ を零とした。

\section{2 電源容量}

スターラの誘導負荷（抵抗を無視したとき）に対す る一相当りの電源容量 $Q$ は, 次式により算出される。

$$
\begin{aligned}
& Q=\omega \Phi I=\omega L I^{2} \\
& \Phi=N \oint_{c} \boldsymbol{A} \cdot \boldsymbol{t} d \boldsymbol{l} \\
& L=\Phi / I
\end{aligned}
$$

ここで， $\Phi$ : コイルの鎖交磁束， $L$ : 負荷インダクタ ンス, $I$ : 負荷電流, $N$ : コイル巻数, $\boldsymbol{t}$ : コイルの電流 方向ベクトル, $l$ : コイル長, $c$ : コイルに沿った積分 路である。

$\omega$ と $I$ が一定なら $Q$ の大きさは $L$ に比例するため, $Q$ を比較する場合は $L$ の值で評価することにした。

\section{3 目的関数}

スターラの場合，電磁力を大きくして攪拌力を増す ために磁束密度 $B_{\mathrm{P}}$ は大きく, 電源容量 $Q$ に関するイ ンダクタンス $L$ は小さく, というのが一般的な目標と なる。目標となる指定点（後述の Fig. 4 の P 点）にお ける磁束密度 $B_{\mathrm{P}}$ とインダクタンス $L$ を用いて, 設計検 討に必要な以下の 4 種類の目的関数 $F_{1} \sim F_{4}$ を考える。 $I$ とを一定とした条件で設計変数を変化させて磁界 解析を行い, 目的関数 $F_{1} \sim F_{4}$ を最小にする問題になる。

$$
\begin{aligned}
& F_{1}=1 / B_{\mathrm{P}} \rightarrow \text { min } \\
& F_{2}=L \rightarrow \text { min } \\
& F_{3}=L / B_{\mathrm{P}} \rightarrow \text { min } \\
& F_{4}=L / B_{\mathrm{P}}{ }^{2} \rightarrow \text { min }
\end{aligned}
$$

$F_{1}$ は $B_{\mathrm{P}}$ を最大にし電磁力を大きくするもの, $F_{2}$ は $L$ を最小にし(2)式の電源容量 $Q$ を小さくするもの, $F_{3}$ は電磁力に関する $B_{\mathrm{P}}$ は大きく $Q$ に関する $L$ は小さく, という目標を表現したものである。 $F_{4}$ は電磁力が $B_{\mathrm{P}}$ の2乗に比例するので $F_{3}$ の分母を変形したものである。

ここで， $F_{4}$ の逆数をとった評価指数 $G$ を定義する。

$$
G=B_{\mathrm{P}}{ }^{2} / L
$$

$F_{4}$ の最小值は $G$ の最大值を表し, 電磁力と容量の比, すなわち電磁的な効率の最大化を意味するものになる。

\section{$2.4 \mathrm{RBM}$ のパラメータ}

RBM により最適化を行う際のパラメータとして, 自由に調整できるもののみ注目し[4]，一つの探索方向 における反復時の判定を以下のように行った（付録 2 参照）[5]。

$<$ 探索成功 $>$

$$
\begin{gathered}
\boldsymbol{D}^{(k+1)}=\boldsymbol{D}^{(k)}+\lambda_{j}^{(k)} \boldsymbol{s}_{j}^{(k)} \\
\lambda_{j}^{(k+1)}=\alpha \lambda_{j}^{(k)} \\
(j=1 \ldots m)
\end{gathered}
$$

$<$ 探索失敗 $>$

$$
\begin{array}{r}
\boldsymbol{D}^{(k+1)}=\boldsymbol{D}^{(k)} \\
\lambda_{j}^{(k+1)}=-\beta \lambda_{j}^{(k)}
\end{array}
$$

ここで, $\boldsymbol{D}$ : 設計変数, $\boldsymbol{s}$ : 探索方向ベクトル, $\lambda_{j}$ : 設計変数 $j$ の刻み幅, $k$ : 反復回数, $m$ : 設計変数の数,

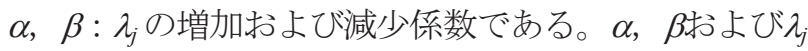
は，一定の範囲で任意に設定でき，これにより寸法変 化の大きさを調整できる。

収束判定は，次式により行い， $\varepsilon=10^{-2}$ とした。

$$
\begin{gathered}
\max \left(\lambda_{j}\right)<\varepsilon \\
\lambda_{j}{ }_{j}=\lambda_{j}\left(D^{(0)}{ }_{j}-D_{j \min }\right)
\end{gathered}
$$

ここで, $D_{j}^{(0)}$ : 設計変数 $j$ の初期值, $D_{j \min }$ : 設計変数 $j$ の可動範囲の最小值である。

\section{5 要素分割}

$\mathrm{RBM}$ と 3 次元磁界解析の組み合わせでは, RBM の 形状変更の度に FEM の分割を変更する必要があり, 次のような簡略化を工夫した。LIM の形状が直交格子 に適応するので，座標軸に平行な直交格子による一次 直方体要素を考えた。 $x, y, z$ 各軸の格子番号を原点 から数えて $i, j, k$ とすると, 節点番号 $n$ の $x, y, z$ の 各座標值 $x(n), y(n), z(n)$ は次式で与えられる。

$$
\begin{aligned}
& x(n)=x x(i), y(n)=y y(j), z(n)=z z(k) \\
& n=n x \times n y \times(k-1)+n x \times(j-1)+i \\
& (i=1 \sim n x, j=1 \sim n y, k=1 \sim n z)
\end{aligned}
$$

ここで, $x x, y y, z z$ : 各格子座標值, $n x, n y, n z: x$, $y, z$ 各軸の格子数である。

位置や形状の変化も座標軸に沿うものとすれば，格 子座標の夕の変化で節点座標を変えることができる。 最も簡単なアルゴリズムとして軸ごとに可動格子点座 標をその前後の格子点で平均化する一種のスムージン グ法[4]が考えられる。しかし, 変化が大きくなれば格 子分割の疎密のバランスが悪くなるため, Fig. 1 のよ うな「格子分割入替アルゴリズム」を考えた。

Fig. 1(a) に示すような, ある方向に対する 3 領域 $\mathrm{S}_{1}$, 
$\mathrm{S}_{2}, \mathrm{~S}_{3}$ があるとし, 領域毎に等分割されているとする。 $\mathrm{S}_{2}$ 領域が(b)図に示す方向に動いたときの格子間隔 $\mathrm{H}_{1}$ と $\mathrm{H}_{3}$ の大きさの比率が一定值以上に広がった場合に $\mathrm{S}_{1}$ と $\mathrm{S}_{3}$ の両領域での総分割数は変化させることなく, 領域毎の分割数を増減し, (c)図のように疎密を緩和さ せるものである。Fig. 2 に, 解析の全体フローを示す。

\section{3 スターラモデルと順解析}

Fig. 3 にスターラの構成を示す。高温の溶鋼（キュ リ一点を越えるため非磁性, 導電性) を入れる容器は,

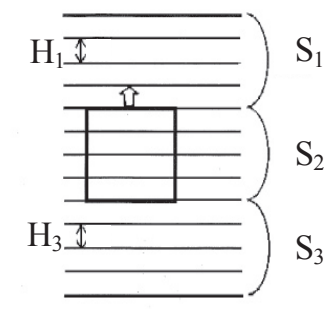

(a) Initial

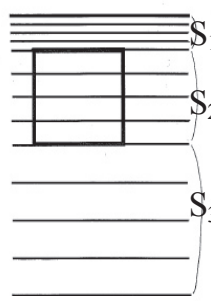

(b) Before

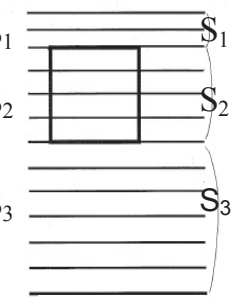

(c) After

Fig. 1 Changing the lattice.

耐火物壁をステンレスで覆い保護する構成にしている。 容器の形状は多種多様で，その利用形態もさまざまで

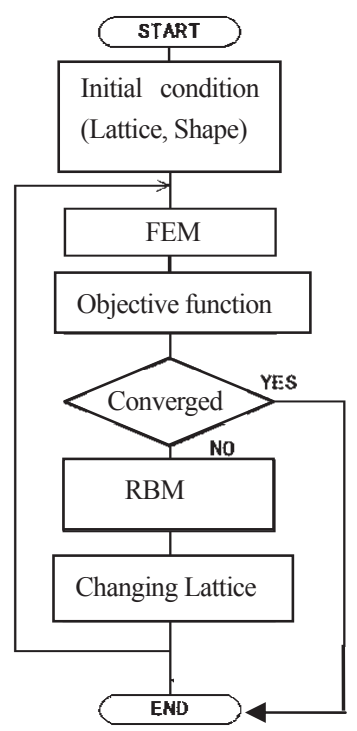

Fig. 2 Flow of analysis.

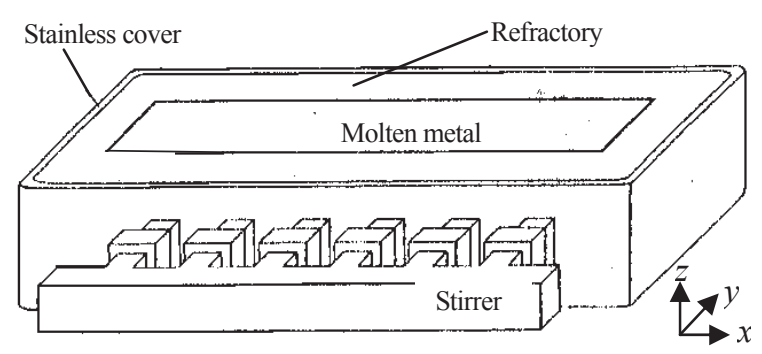

Fig. 3 Configuration of stirrer.

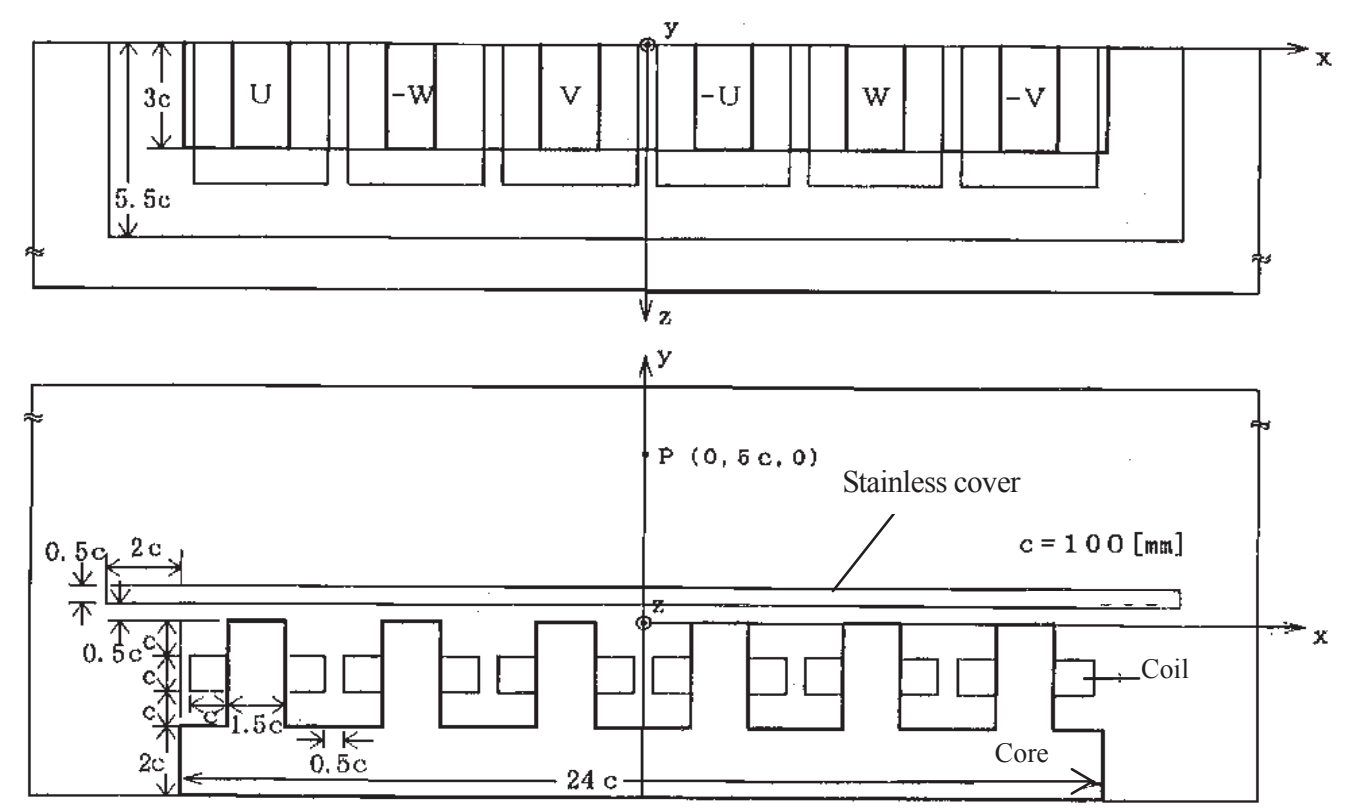

Fig. 4 Analysis model. 
Table 1 Calculation condition.

\begin{tabular}{|l|l|}
\hline Number of phase & 3 \\
\hline Connection & Star \\
\hline Frequency $(\mathrm{Hz})$ & 5 \\
\hline Current $(\mathrm{A})$ & 2000 \\
\hline Number of turns of one coil & 32 \\
\hline Number of poles & 2 \\
\hline Slots per phase per pole & 1 \\
\hline Slot pitch $(\mathrm{m})$ & 0.4 \\
\hline Pole pitch $(\mathrm{m})$ & 1.2 \\
\hline Permeability of core & 1000 \\
\hline Conductivity $(\mathrm{S} / \mathrm{m})$ & $1.439 \times 10^{6}$ \\
\hline Synchronous speed $(\mathrm{m} / \mathrm{s})$ & 12 \\
\hline
\end{tabular}

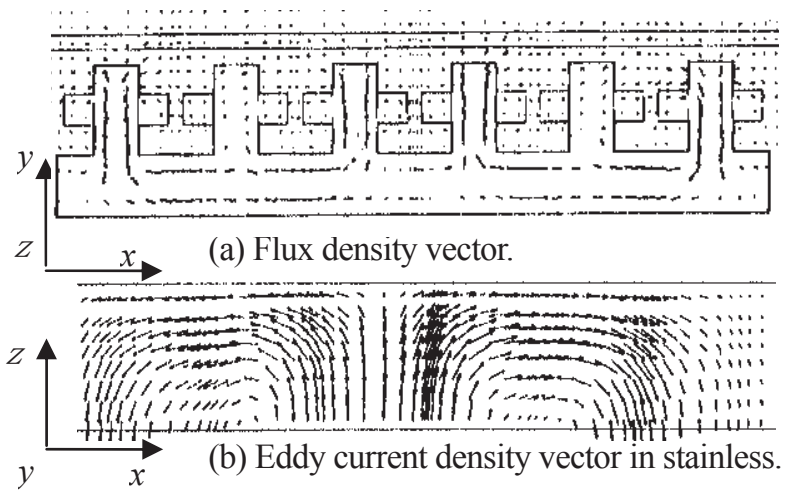

Fig. 5 Distributions of eddy current and flux $\left(\omega t=30^{\circ}\right)$.

あるがここでは平板形を対象にした。

Fig. 4 に計算モデルを, Table 1 に解析諸元や解析条 件を示す。順解析では渦電流を考慮するため, 解析領 域は $1 / 2$ （コイル 6 個分）とした。

Fig. 5 に U 相基準で $\omega t=30^{\circ}$ の時の磁束密度とステ ンレスカバー内の渦電流密度のベクトル図を示す。こ こで，U 相コイルの電流が最大になる瞬間を時間の基 準 $\left(\omega t=0^{\circ}\right)$ にとった。起磁力は空間的に対称であるが ステンレスカバーに誘導された電流による位相遅れの ため, ベクトル図は対称にならない。

Fig. 6 に，中心線上 $(x=z=0 \mathrm{~mm})$ でコア表面から $y$ 方向の距離に対する磁束密度の $y$ 方向成分 $B_{y}$ の変化を 示す。ステンレスカバーの有無による溶湯内の代表点

(Fig. 4 に示した P 点) の $B_{y}$ の変化はわずかである。 つまり交流磁界を印加してステンレスに渦電流が流れ た場合と直流電流を流した静磁界の場合の $B_{\mathrm{P}}$ の差が 小さいので, 計算時間を減らすために以下の最適化計 算ではステンレスが無い場合（静磁界解析，1/4 モデ ル）について解析を行った。本論文の目的は，スター ラの最適設計に関するものであり, 磁束密度の值その

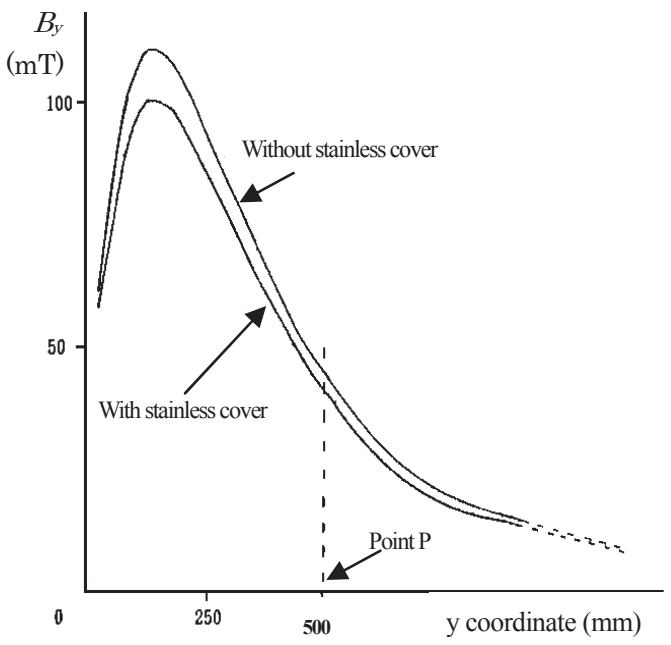

Fig. $6 \quad B_{y}$ along the central axis $(x=z=0)$.

ものを議論する訳ではないので，静磁界解析で十分で ある。実機に適用する場合は，予めこの差の程度を把 握しておいて見積もればよいと考えられる。

\section{4 最適化計算}

\section{1 最適化モデル}

Fig. 7 に，ティースとコイルの設計変数 $D_{1}, D_{2}, D_{3}$ とその変化の範囲を示す。 $D_{1}$ はコイルの $y$ 方向位置 (高 さ), $D_{2}$ はコイルの高さ方向長さ， $D_{3}$ はティース幅で ある。コイル断面積は一定とした。よってコイル幅は $D_{2}$ により従属的に変化する。各設計変数の可動範囲

（構造上から規定される寸法上の制約条件）を Table 2 のように設定する。各条件はそのすべてを同時に満足 しなければならない。RBM は最適解の唯一性が保証さ れないので，3 つのケースの初期寸法を仮定した。設 計目標は Fig. 4 の P 点の磁束密度の $y$ 方向成分 $B_{y}$ が $43 \mathrm{mT}$ 以上とし，その他の計算条件は Table 1 の通りと した。

\section{2 計算結果}

Table 3 に初期值を， Table 4 にその計算結果を示す。 各ケース名 $\mathrm{Aab}$ で次のような場合を表した。頭字 $\mathrm{A}$, B，C で初期值の違いを, 添字 $\mathrm{a}$ は 1 が目的関数 $F_{1}$ の 場合, 2 が $F_{2}$ の場合， 3 が $F_{3}$ の場合， 4 が $F_{4}$ の場合を 示す。設計変数欄の一記号は該当する設計变数を初期 值に固定したことを示す。添字 b は 0 が初期形状の場 合，1 は $D_{1}$ のみを，2 は $D_{2}$ のみを， 3 は $D_{3}$ のみを変 化させた場合である。4 は $D_{1}, D_{2}$ がともに変化する場 合, 5 は $D_{1}, D_{2}, D_{3}$ がともに変化する場合を示す。Table 3 の初期值 $\mathrm{A} 00, \mathrm{~B} 00, \mathrm{C} 00$ としては， $D_{1}$ と $D_{3}$ は Fig. 4 


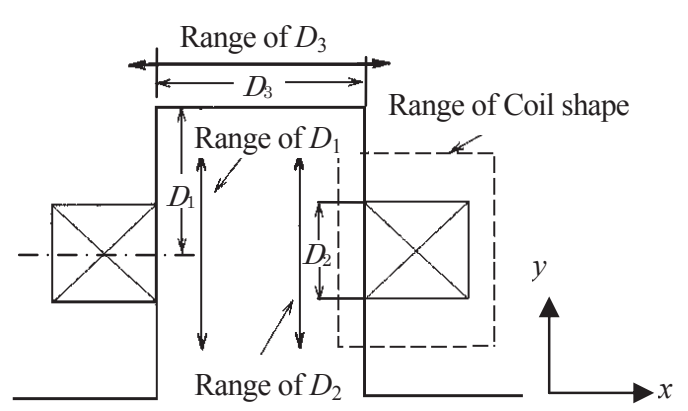

Fig. 7 Design variables and range of variable.

Table 2 Range of the design variables.

\begin{tabular}{|l|l|}
\hline & Range $(\mathrm{mm})$ \\
\hline (A) & $50 \leqq D_{1} \leqq 250$ \\
\hline (B) & $50 \leqq D_{2} \leqq 200$ \\
\hline (C) & $125 \leqq D_{3} \leqq 175$ \\
\hline \hline (D) & $D_{1}+D_{2} / 2 \leqq 275$ \\
\hline (E) & $25 \leqq D_{1}-D_{2} / 2$ \\
\hline (F) & $10000 / D_{2}+D_{3} / 2 \leqq 181.25$ \\
\hline
\end{tabular}

Table 3 Initial condition

\begin{tabular}{|c|c|c|c|}
\hline & $D_{1}$ & $D_{2}$ & $D_{3}$ \\
\hline $\mathrm{A} 00$ & 150 & 100 & 150 \\
\hline $\mathrm{B} 00$ & 150 & 200 & 150 \\
\hline $\mathrm{C} 00$ & 150 & 150 & 150 \\
\hline
\end{tabular}

に示したティースおよびコイル位置に等しいとし， $D_{2}$ を 100，200，150 と変化させた。Table 4 の $F_{1}$ に関す る $\mathrm{A} 11 〜 \mathrm{~A} 15$ や B11〜B15 の結果から, A15 や B15 が 最も $B_{\mathrm{P}}$ が大きく, また, $F_{2}$ に関する $\mathrm{A} 21 \sim \mathrm{A} 25$ や $\mathrm{B} 21$ 〜B25 からは, A25 やB25 が最も $L$ が小さくなってお り, 設計変数 $D_{1}, D_{2}, D_{3}$ を同時に変化させた場合が 最も目標值を満足するものになっている。

目的関数の違いによるケース Aa5, Ba5, $\mathrm{Ca} 5(\mathrm{a}=1$ 〜4)の結果から次のことが分かる。Fig. 8 は初期值の違 いによる最適解 (A45, B45, C45) の比較である。評 価指数 $G$ は同程度であるが $D_{1}, D_{2}, D_{3}$ は異なったも のであり, 解は一意ではない (局所的最適解)。このよ うに複数の解を得られるのが RBM の特長であり, 多 様な構成の検討が可能になる。

Fig. 9 に目的関数值（初期形状の值に対する比）と 各目標值の関係を示す。(a)は $F_{1}$ に関するもので, $F_{1}$ が小さいほど目標值の $B_{\mathrm{P}}$ が大きくなっているが， $B_{\mathrm{P}}$ と共に $L$ も大きくなっている。(b)は $F_{2}$ に関するもの で， $F_{2}$ が小さくなると $L$ もさくなるが， $B_{\mathrm{P}}$ も小さく なっている。これより, 目的関数 $F_{1}, F_{2}$ では「 $B_{\mathrm{P}}$ は大 きく $L$ は小く」という目標を満たすことができない
Table 4 Result $\left(\alpha=1.0, \beta=0.5, \lambda^{\prime}=0.1, \varepsilon=0.01\right)$

\begin{tabular}{|c|c|c|c|c|c|c|c|c|c|c|}
\hline \multirow[t]{2}{*}{ Case } & \multirow[b]{2}{*}{ State } & \multicolumn{3}{|c|}{ Design Variable } & \multicolumn{2}{|c|}{$\begin{array}{l}\text { Objective } \\
\text { Function }\end{array}$} & \multicolumn{2}{|c|}{$\begin{array}{l}\text { Target } \\
\text { Value }\end{array}$} & \multirow{2}{*}{\begin{tabular}{|l|}
$G$ \\
$B_{\mathrm{P}}{ }^{2} / L$
\end{tabular}} & \multirow{2}{*}{$\begin{array}{l}\text { RBM } \\
\text { Number } \\
\text { of } \\
\text { Iteration }\end{array}$} \\
\hline & & \begin{tabular}{|l|}
$D_{1}$ \\
$(\mathrm{~mm})$
\end{tabular} & \begin{tabular}{|l|}
$D_{2}$ \\
$(\mathrm{~mm})$
\end{tabular} & $\begin{array}{l}D_{3} \\
(\mathrm{~mm})\end{array}$ & Type & \begin{tabular}{|l} 
Relativ \\
Ratio
\end{tabular} & \begin{tabular}{|l|}
$B_{\mathrm{P}}$ \\
$(\mathrm{mT})$
\end{tabular} & $\begin{array}{l}L \\
(\mathrm{mH})\end{array}$ & & \\
\hline & & & & & & & & & & \\
\hline 11 & Final 2 & 218.8 & - & - & \multirow{5}{*}{$F_{1}$} & 0.959 & 47.0 & 5.132 & 430 & 11 \\
\hline A12 & Final & - & 94.4 & - & & 0.959 & 45.2 & 4.202 & 486 & 8 \\
\hline A13 & Final & - & - & 162.2 & & 0.981 & 46.0 & 4.305 & 492 & 9 \\
\hline A14 & Final 2 & 220.2 & 95.0 & - & & 0.958 & 47.1 & 5.131 & 432 & 22 \\
\hline A15 & Final 2 & 220.4 & 96.9 & 155.3 & & 0.951 & 47.4 & 5.186 & 433 & 36 \\
\hline A21 & Final & 81.3 & - & - & \multirow{5}{*}{$F_{2}$} & 0.767 & 41.6 & 3.236 & 535 & 19 \\
\hline A22 & Final & - & 94.4 & - & & 0.996 & 45.2 & 4.202 & 486 & 8 \\
\hline A23 & Final & - & - & 126.6 & & 0.962 & 43.3 & 4.060 & 462 & 24 \\
\hline A24 & Final & 74.1 & 94.8 & - & & 0.740 & 41.3 & 3.123 & 546 & 52 \\
\hline $\mathrm{A} 25$ & Final & 68.5 & 85.0 & 126.7 & & 0.685 & 39.2 & 2.890 & 532 & 77 \\
\hline A35 & Final & 72.5 & 92.6 & 143.6 & $F_{3}$ & 0.803 & 40.7 & 3.058 & 542 & 72 \\
\hline $\mathrm{A} 45$ & Final & 74.6 & 96.9 & 155.4 & $F_{4}$ & 0.877 & 41.7 & 3.163 & 550 & 61 \\
\hline & & & & & & & & & & \\
\hline \begin{tabular}{|l|} 
B11 \\
\end{tabular} & Final & 168.8 & - & - & & 0.981 & 44.9 & 4.342 & 464 & 6 \\
\hline B12 & Final & - & 110.0 & - & & \begin{tabular}{|l|}
0.980 \\
\end{tabular} & 45.0 & 4.239 & 478 & 19 \\
\hline B13 & Final & - & - & 172.2 & & \begin{tabular}{|l|}
0.964 \\
\end{tabular} & 45.7 & 4.218 & 495 & 13 \\
\hline \begin{tabular}{|l|} 
B14 \\
\end{tabular} & Final & 226.3 & 94.2 & - & & 0.933 & 47.2 & \begin{tabular}{|l|}
5.196 \\
\end{tabular} & 429 & \begin{tabular}{|l|}
57 \\
\end{tabular} \\
\hline B15 & Final & 221.4 & 106.8 & 174.9 & & \begin{tabular}{|l|}
0.906 \\
\end{tabular} & 48.6 & \begin{tabular}{|l|l|}
5.389 \\
\end{tabular} & 438 & 86 \\
\hline B21 & Final & 131.3 & - & - & & 0.930 & 43.1 & 3.784 & 491 & 9 \\
\hline B22 & Final & - & \begin{tabular}{|l|}
198.1 \\
\end{tabular} & - & & 1.002 & 44.1 & 4.074 & 477 & 3 \\
\hline \begin{tabular}{|l|}
$\mathrm{B} 23$ \\
\end{tabular} & Final & - & - & 126.6 & & \begin{tabular}{|l|}
0.962 \\
\end{tabular} & 42.2 & 3.911 & 55 & 24 \\
\hline B24 & Final & 130.0 & \begin{tabular}{|l|l|}
198.1 \\
\end{tabular} & - & & \begin{tabular}{|l|l}
0.927 \\
\end{tabular} & 43.0 & 3.772 & 490 & 18 \\
\hline \begin{tabular}{|l|}
$\mathrm{B} 25$ \\
\end{tabular} & Final & 125.3 & 200.0 & 126.6 & & \begin{tabular}{|l|}
0.870 \\
\end{tabular} & \begin{tabular}{|l|}
40.8 \\
\end{tabular} & 3.540 & 470 & 75 \\
\hline B35 & Final & 125.0 & 200.0 & 167.5 & $F_{3}$ & 0.934 & 44.0 & 3.979 & 487 & 39 \\
\hline \multirow[t]{2}{*}{ B45 } & Final & 125.0 & 200.0 & 174.1 & $F_{4}$ & 0.925 & \begin{tabular}{|l|}
44.5 \\
\end{tabular} & 3.839 & 516 & 48 \\
\hline & & & & & & & & & & \\
\hline C15 & Final & 223.0 & 102.9 & 164.9 & $F_{1}$ & 0.932 & 48.1 & 5.312 & 436 & 38 \\
\hline \begin{tabular}{|l|}
$\mathrm{C} 25$ \\
\end{tabular} & Final & 115.0 & 179.9 & 125.3 & $F_{2}$ & 0.814 & \begin{tabular}{|l|}
40.3 \\
\end{tabular} & 3.456 & 470 & 78 \\
\hline \begin{tabular}{|l|} 
C35 \\
\end{tabular} & Final & 73.8 & 96.9 & 154.5 & $F_{3}$ & 0.798 & \begin{tabular}{|l|}
41.6 \\
\end{tabular} & 3.145 & 550 & 62 \\
\hline \begin{tabular}{l|l}
45 \\
\end{tabular} & Final & 79.1 & 102.5 & 166. & $F_{4}$ & 0.854 & 42.8 & 3.304 & 554 & 60 \\
\hline
\end{tabular}

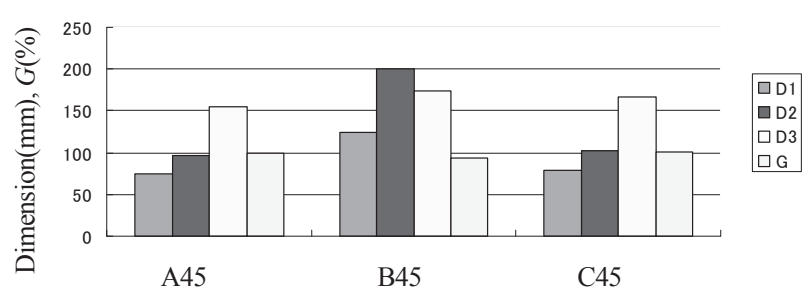

Fig. 8 Influence of initial value.

ことが分かる。(c)は $F_{3}$ に関するもので， $F_{3}$ が小さい 時に $B_{\mathrm{P}}$ と共に $L$ も低くなるが, 目標值としている $B_{\mathrm{P}} / L$ 最大化が可能なことを表している。(d)は $F_{4}$ に関するも ので, $F_{4}$ が小さくなると $G=B_{\mathrm{P}}{ }^{2} / L$ が大きくなってい る。(c), (d)を用いれば最適化ができる可能性があるこ とが分かる。 


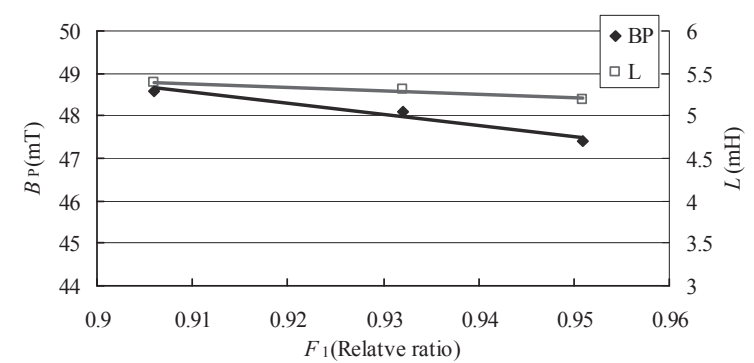

(a) $F_{1}$ and $B_{\mathrm{P}}, L$

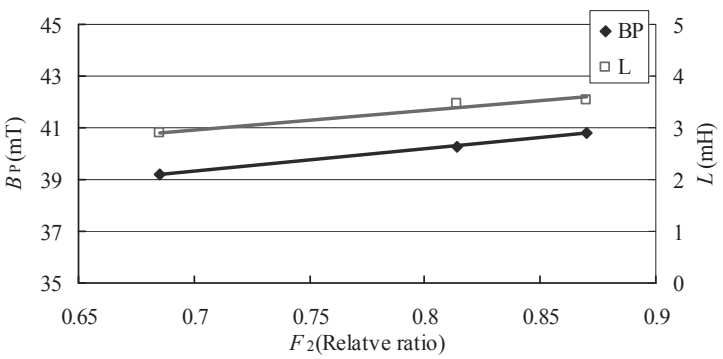

(b) $F_{2}$ and $B_{\mathrm{P}}, L$

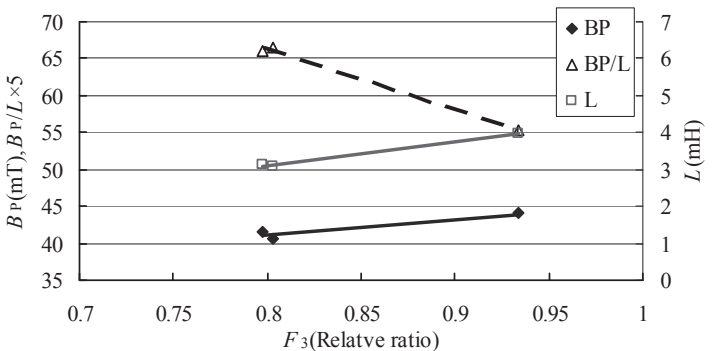

(c) $F_{3}$ and $B_{\mathrm{P}}, L, B_{\mathrm{P}} / L$

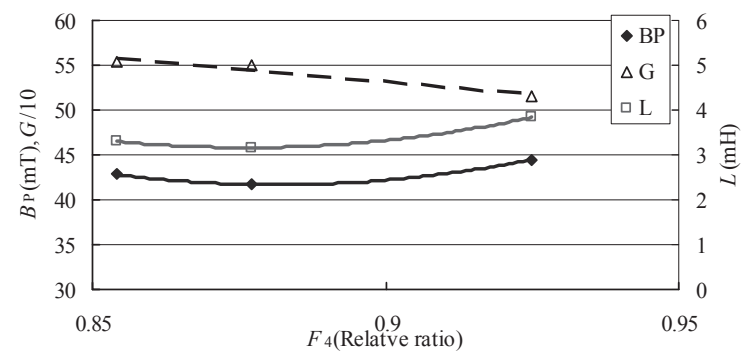

(d) $F_{4}$ and $B_{\mathrm{P}}, L, G$

Fig. 9 Relationship between objective function and target values.

設計変数 $D_{1}, D_{2}, D_{3}$ の効果を明確にするために, 全データについて重回帰分析(MRA:Multiple Regression Analysis)[6]を行った。Fig. 10(a) に設計変数と指定点 $\mathrm{P}$ の磁束密度 $B_{\mathrm{P}}$ の関係を, Fig. 10(b) に $Q$ との関係を示 す。これらの回帰線の方程式と重決定值 $\mathrm{R}^{2}$ も併記した。 Fig. 10 (a)，(b)共に $B_{\mathrm{P}} ， Q$ は $D_{1}$ と強い相関が， $D_{3}$ と弱 い相関が認められるが, $D_{2}$ との相関は認められなかっ た。

Fig. 11 に各目標值間の相関性を示す。Fig. 11(a)は $B_{\mathrm{P}}$

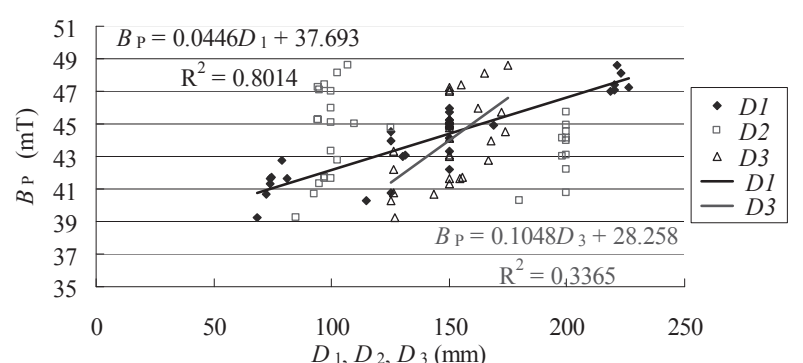

(a) Flux density $B_{\mathrm{P}}$ at specified point.

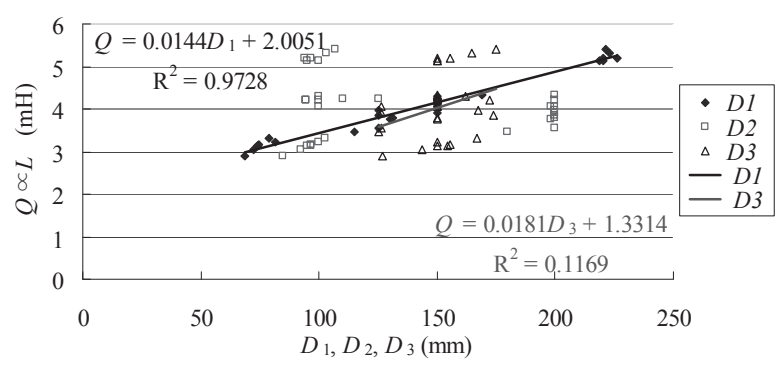

(b) Power source capacity $Q$.

Fig. 10 Correlation between design variables and target values.

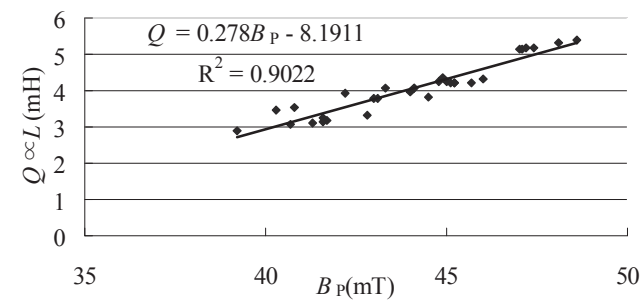

(a) Correlation between $B_{\mathrm{P}}$ and $Q$.

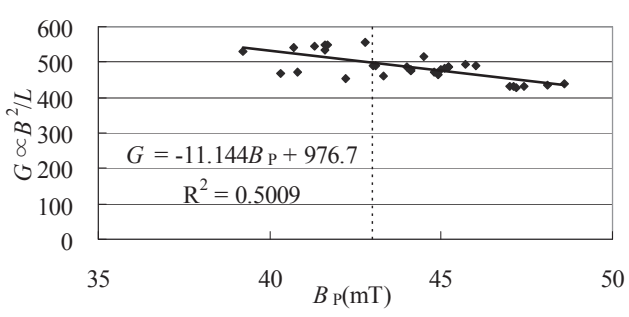

(b) Correlation between $B_{\mathrm{P}}$ and $\mathrm{G}$.

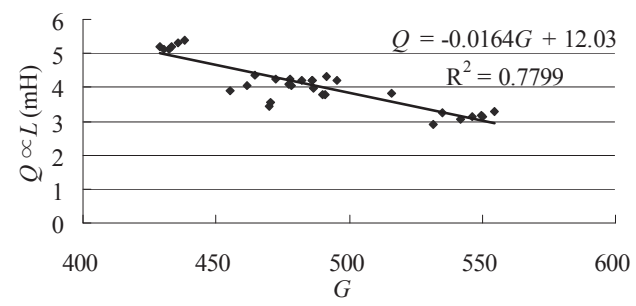

(c) Correlation between $G$ and $Q$.

Fig. 11 Correlation between each target value. 
と $Q$ の関係である。強い正の相関があり， $B_{\mathrm{P}}$ と共に $Q$ も大きくなるため, 最適構成 $\left(B_{\mathrm{P}}\right.$ は大きく $Q$ は小さく) が得難いことが分かる。Fig. 11(b)の $B_{\mathrm{P}}$ と評価指数 $G$ ((9)式で定義) の関係は負の相関があり， $B_{\mathrm{P}}$ を大きく すると磁気効率を表す $G$ が小さくなる。 $B_{\mathrm{P}}$ の規定值 $43 \mathrm{mT}$ での $G$ は設計変数 $D_{1}, D_{2}, D_{3}$ の組み合わせによ り変化する。Fig. 11(c)の $G$ と $Q$ の関係では強い負の相 関があり, Fig. 11(b)と Fig. 11(c)から $B_{\mathrm{P}}$ の規定值や $Q$ を考慮した最適な設計変数の構成を $G$ で評価できる。

$B_{\mathrm{P}}$ と $G$ を重回帰モデル $\left(\mathrm{Y}=\beta_{1} D_{1}+\beta_{2} D_{2}+\beta_{3} D_{3}+\alpha, \mathrm{Y}=B_{\mathrm{P}}\right.$, $\mathrm{Y}=G)$ で解析した。 $\beta_{1}, \beta_{2}, \beta_{3}, \alpha$ は偏回帰係数である。 Fig. 10 から設計変数 $D_{2}$ の相関 $\left(\beta_{2}\right)$ が小さいので, $D_{1}$, $D_{3}$ を用いた次式で表した。

$$
\begin{aligned}
& B_{\mathrm{P}}=0.04 D_{1}+0.07 D_{3}+28.12 \\
& G=-0.786 D_{1}+0.8 D_{3}+491
\end{aligned}
$$

Fig. 12 に $B_{\mathrm{P}}$ や $G$ と設計変数 $D_{1}, D_{3}$ の関係を示寸。直 線 $\mathrm{r}$ は(16)式で $B_{\mathrm{P}}=43$ とした方程式で, 矢印の方向が $B_{\mathrm{P}}>43 \mathrm{mT}$ を満たす解領域である。直線 $\mathrm{q}$ は(17)式で $G$ $=500$ の場合の方程式であり, 矢印の方向が $G>500$ の 解領域を示寸。 $G$ の最大值は $B_{\mathrm{P}}=43 \mathrm{mT}$ の直線 $\mathrm{r}$ と $D_{3}$ の制約条件 $\left(D_{3}=175 \mathrm{~mm}\right)$ の交点（○印の MRA）で表 され，(17)式にこの交点の座標 $\left(D_{1}, D_{3}\right)$ を入力すること により, $G$ の最大值 $G=579$ が得られる (直線 $\mathrm{p}$ )。Table 4 の $F_{4}$ に関する $\mathrm{A} 45(\boldsymbol{O}), \mathrm{B} 45(\boldsymbol{\Delta}), \mathrm{C} 45(\boldsymbol{\square})$ に対応する $D_{1}, D_{3}$ の值も図中に併記した。C45 や A45 は MRA の 值に近く, RBM で $G$ を指標にするのが妥当であると いえる。直線 $\mathrm{p}, \mathrm{r}$ の交点 $\mathrm{a}$, 直線 $\mathrm{q}, \mathrm{r}$ の交点 $\mathrm{e}$, 直線 $\mathrm{q}$ と $D_{3}=175 \mathrm{~mm}$ の交点 $\mathrm{f}$ を結んだ三角形 $\mathrm{a}, \mathrm{e}, \mathrm{f}$ が設 計変数 $D_{1}, D_{3}$ の選定領域で, 実機の設計では, この 中で直線 q（(17)式）を矢印の方向に移動した（G の大 きい方向）構成の検討を行なうことになる。

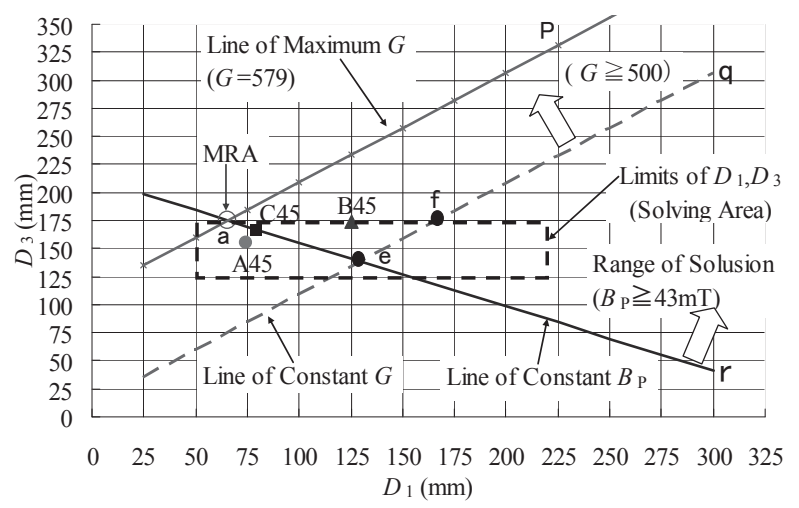

Fig. 12 Relation between design variables and target values.

\section{5 おわりに}

LIM 式スターラの最適構成を検討するために, Rosenbrock 法, 3 次元静磁界解析と重回帰分析を併用 した設計手法を示した。スターラの設計課題は検查点 での磁束密度 $B_{\mathrm{P}}$ の規定值 $B_{\mathrm{N}}$ を満足し, 電源コストに 関係する電源容量 $Q$ を小さくするようにティース寸法 とコイル形状を最適化することである。鉄鋼用は大型 なので，製作性や全体のコストを勘案した構成の調整 を設計者が判断することになる。そこで，次のような (1)最適設計手法と(2)スターラの構成検討法を提案し, (3)スターラの設計パラメータに関する知見を得た。

(1)RBM で設計検討に必要な種々の目的関数 $\left(B_{\mathrm{P}}\right.$ 大, $Q$ 小, $B_{\mathrm{P}} / Q$ 大, $B_{\mathrm{P}}{ }^{2} / Q$ 大） での多数の最適解グルー プを求め, この結果を重回帰分析して各設計変数の 寄与を確認する。このために次のように磁界解析を 工夫した。

(1)平板型スターラの形状に適応する直交格子分割を採 用し, RBM の反復計算におけるコイルなどの対象物 の位置の変化をスムージング法で処理することで円 滑な解析が行えるようにした。

(2)スターラのような低周波の渦電流問題では，指定点 の磁束密度を求める際に静磁界解析で代用できるこ とを確認し, 3 次元磁界解析を用いた最適化解析の 計算時間と記憶容量の節減を行った。

(2)設計課題の電源容量 $Q$ を小さくするには漏孔磁束 が小さい磁気効率の良い構成にすることであり, 設 計指標に磁気効率を表す評価指数 $G$ を採用した。

(1) $B_{\mathrm{P}}$ の規定值 $B_{\mathrm{N}}$ を満たし製作性やコストを勘案して $G$ を大きくする構成を選定すればよいことを示した。 (2)重回帰分析の結果を図式解法で $B_{\mathrm{P}} \geqq B_{\mathrm{N}}$ で $G$ が大 きくなるものを適宜選定することで, 意図する設計 検討が可能になるようにした。

(3) $B_{\mathrm{P}}$ や $Q$ と設計変数 $D_{1}, D_{2}, D_{3}$ の間の関係について の知見を得ることができた。コイルの位置 $D_{1}$ やティ 一ス幅 $D_{3}$ が $B_{\mathrm{P}}$ や $Q$ に及ぼす影響が大きいが，コイ ルの形状 $D_{2}$ の影響は小さい。よって, 最良の条件を $D_{1}$ と $D_{3}$ の組み合わせで求められる。また， $D_{2}$ は特 性に影響しないために生産性やコストを配慮して任 意の形状に設定できる。 


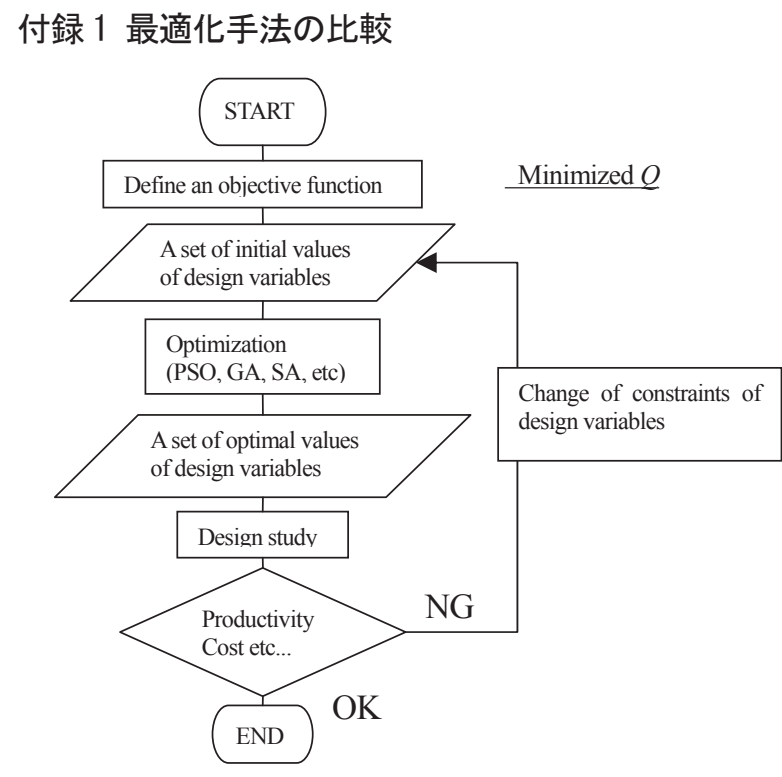

Fig. 13 Flow of ordinary method.

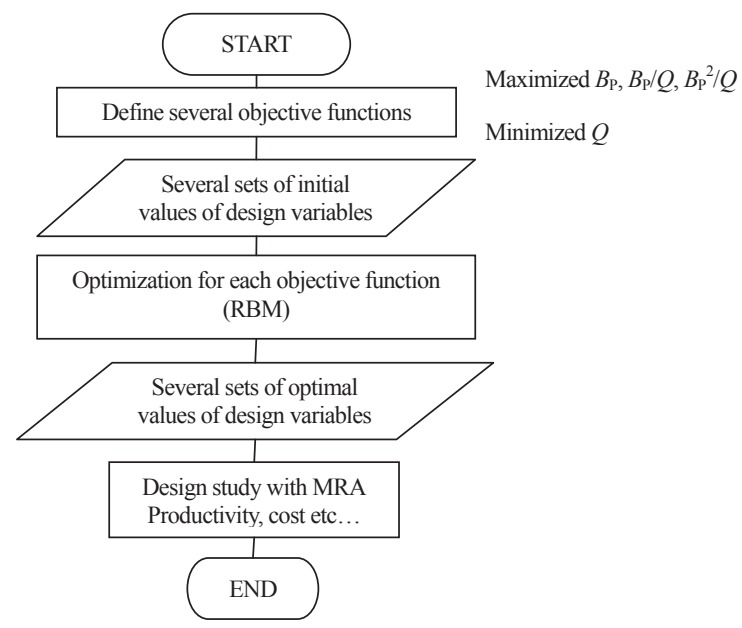

Fig. 14 Flow of proposed method.

\section{付録 2 ローゼンブロック法[5]}

これは目的関数 $W$ が最大または最小になる寸法な どを順次探索する手法である。この手法では現在求ま っている近似解に対して，さらに部分的な修正を繰り 返し行うことによって, より良い近似最適解を求める。

Fig. 15 は寸法 $L_{1}, L_{2}$ を変えて目的関数 $W$ を計算し, その等高線を描いたものである。Wが最小になる谷底 に対応する $L_{1}$ と $L_{2}$ を求めれば, それが最適解である。

本論文では設計変数 $D_{1}, D_{2}, D_{3}$ などが $L_{1}$ や $L_{2}$ に, 目的関数 $F_{1}, F_{2}, F_{3}, F_{4}$ などが $W$ に対応する。

具体的には次のように処理する。

最初に $L_{1}, L_{2}$ の初期值 $L_{1}{ }^{(0)}, L_{2}{ }^{(0)}$ を与えておき, 刻 み幅 $\Delta L_{1}, \Delta L_{2}$ により $L_{1}$ と $L_{2}$ の寸法を交互に少しずつ

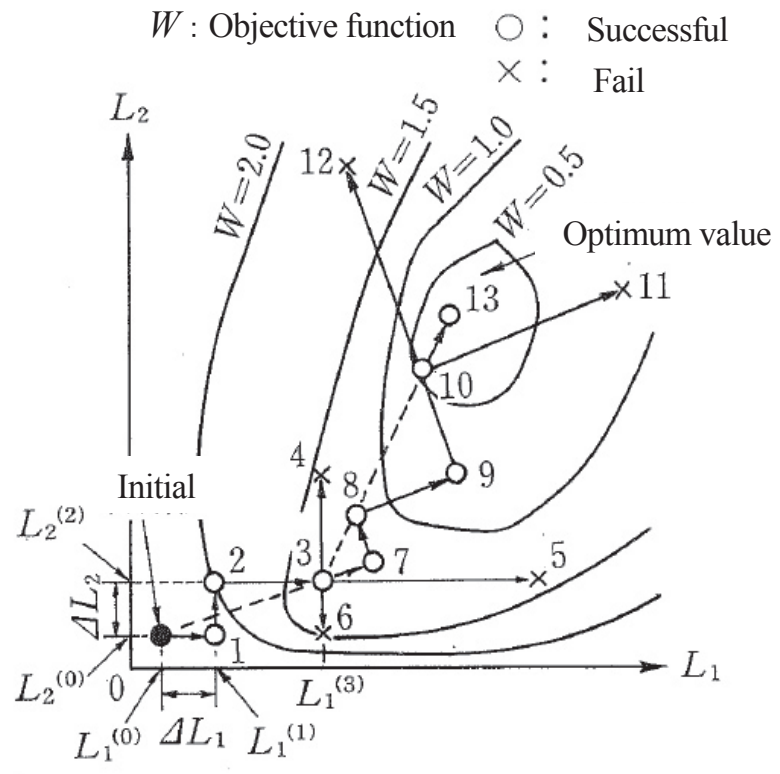

Fig. 15 Concept of Rosenbrock's method.

変化させて $L_{1}{ }^{(1)}=L_{1}{ }^{(0)}+\Delta L_{1}, L_{2}{ }^{(2)}+L_{2}{ }^{(0)}+\Delta L_{2}$ とし, $W$ が小さくなる方向を探し，その方向でさらに寸法を $L_{1}{ }^{(3)}=L_{1}{ }^{(1)}+\Delta L_{1}$ に変化させるという手順を 1 から 13 (Fig. 15 中の○印や×印) まで繰り返す。刻み幅 $\Delta L_{1}$ や $\Delta L_{2}$ は探索の成功, 失敗に応じて変化させる。3では 刻み幅を変更しても×印の $4,5,6$ などは $W$ を小さく する方向にならず，○印の 7 の方向で成功したことを 表している。7 の方向は 0 と 3 を結ぶ方向 (0, 1，2， 3 まで成功しているので) であり，3 では新たにこの方 向を基準軸にして 7，8，9，10 と進む。10 において， 11 や 12 の方向では失敗なので, 3 と 10 を結ぶ方向 (3, 7，8，9，10まで成功しているので）に進み 13 で成功 する。

目的関数の微係数を用いずに, ある刻夕幅 $\Delta L$ ずつ変 えて最適解の探索を行うため, (降下法に比べると収束 は遅いが）解が振動・発散して求まらないことはほと んどなく，微分不可能な関数の場合や局所的最適解を 有する場合でも解を探索できるので，「手堅い小手法で あるといえる。

（2011年 9 月 9 日受付, 2012 年 10 月 12 日再受付, 2013 年 7 月 26 日再々受付)

\section{参考文献}

[1] L.E.Coelho, L.Z.Barbosa, and L.Lebensztajn, Multiobjective Particle Swarm Approach for the Design of a Brushless DC Wheel Motor, IEEE Trans. Magn., Vol.46, No.8, pp. 2994-2997, 2010. 
[2] 高橋, 藤原, 磁界問題の最適設計法, 第 5 回電磁界数值 解析に関する若手セミナ一講演論文集, pp.11-25, 1994.

[3] 高橋, 中田, 大橋, 宮田, 有限要素法と数理計画法を用 いた非線形最適設計法の応用, 電気学会静止器・回転機 合同研究会資料，SA-94-17, RM-94-81, 1994.

[4] 成田, 河辺, 下村, 磁界解析最適化計算におけるスムー ジング要素分割, 電気学会静止器・回転機合同研究会資 料, SA-96-03, RM-96-53, 1996.

[5] 高橋, 磁界系有限要素法を用いた最適化, 森北出版, 2001.

[6] 田中, 垂水, 脇本, パソコン統計解析ハンドブック II 多 変量解析編，共立出版，pp. 1-70,1988. 